\title{
FuZZY-BASED TEMPERATURE CONTROLLER FOR CULTURING MESOPHILIC AND THERMOPHILIC BACTERIAL USING FIRING ANGLE
}

\author{
Iliya Tizhe Thuku ${ }^{\text {, Allo Iliya Alhassan }}{ }^{2}$ and Adamu Shuaibu Kadalla ${ }^{3}$ \\ ${ }^{1}$ Department of Electrical and Electronic Engineering, \\ Modibbo Adama University, Yola Nigeria \\ ${ }^{2}$ Federal Polytechnic Mubi, Adamawa State, Nigeria \\ ${ }^{3}$ Department of Electrical and Electronic Engineering, \\ Modibbo Adama University, Yola Nigeria
}

\begin{abstract}
Temperature control is an important parameter in the fields of engineering and medical Laboratory. Culturing of micro bacteria and enzymes for the purpose of medical diagnoses or process development in manufacturing industries require their optimum temperature to be monitored and control. In this research work Fuzzy logic controller was designed to control the incubator Temperature, by computing appropriate firing angle. MATLAB Simulink toolbox was used for simulation. The results show that the fuzzy logic controller tracks the optimum Temperature for culturing Mesophilic and Thermophilic bacteria at $37.5^{\circ} \mathrm{C}$ and $55.2^{\circ} \mathrm{C}$ respectively. The transient response shows an overshot of $0.5 \%$ for the two responses. The rise time were $787 \mathrm{~ms}$ and $792 \mathrm{~ms}$ for 310.5 Kelvin and 328.2 Kelvin respectively. The settling time for the 310.5 Kelvin response was $1 \mathrm{~s}$; whereas it took $2 \mathrm{~s}$ for the 328.2 Kelvin response to attain steady state.
\end{abstract}

\section{KEYWORDS}

Temperature, Bacteria, Thermophilic, Mesophilic, Fuzzy logic, \& Firing Angle.

\section{INTRODUCTION}

Temperature control is a cardinal issue that affects human living as well as micro-bacterial survival in their natural habitation. Temperature is an essential physical quantity which is found in most application of home appliances, scientific laboratories equipment and industrial processes. Scientific processes such as chemical reactions, equipment manufacturing and process control also rely heavily on the stability of temperature at certain threshold in order to give optimum performance. The main issue in every temperature control strategy is to monitor and maintain temperature status of facilities [1].

Temperature variation is one of the most important stress factors for microorganism in their environment. For instance, a temperature increase induces the bacterial heat Shock response which allows cells to adapt and survive against the thermal stress conditions [2]. Most bacteria grow within a particular temperature range. The minimum growth temperature is the lowest temperature at which a particular bacterium can still grow, while the maximum growth temperature is the highest temperature at which a bacterium can still grow. The optimum growth temperature, however, is the temperature at which the bacterium grows at its highest rate. When an organism is grown below its optimum and above its minimum temperature, it grows much more slowly because the metabolic enzymes are performing inadequately for maximum growth 
and the plasma membrane becomes rigid and unable to transport nutrients effectively. Likewise, when an organism is grown above its optimal temperature the metabolic enzymes start to denature and quickly become nonfunctional, which slows the growth and actually kills the organisms when the temperature is too elevated.

[2], observed that "living organisms contain many genes encoded in their DNA sequences. Each gene contains the information needed for the cell to produce a specific protein or enzyme required to carry out a particular biochemical function or to fulfil a particular cellular process. Factors such as $\mathrm{pH}$, light, and temperature may cause certain genes to be "turned on" or to be "turned off" under certain conditions. In other words, although the gene is always present in the organism's DNA, a variety of stimulants or inhibitors may cause gene expression (the transcription of the gene DNA to produce mRNA) to start or stop, respectively [2]. Ultimately, if gene expression is turned off, the appropriate mRNA is not produced and translation will not occur. Since the corresponding proteins are not produced, the cellular function controlled by that gene stops and the gene is no longer expressed. There is therefore the need to operate at optimum temperature particularly in culturing thermophilic bacteria [1].

Growth of bacteria on the surface of the eggshells and penetration of those microbes into the egg may be affected by ambient environmental conditions, in particular temperature and humidity [3]. This mean that if the right temperature is not provided for incubation of eggs such eggs may be contaminated by bacterial and may never mature to produce chicks, thereby causing economic loss. The same is applicable to bacteria that aid fermentation processes [3].

Bacterial and microorganisms are identified from their host samples via a process called Culturing. Culturing involve conditioning of bacterial or microscopic organisms under certain temperature and other factors such as humidity, for a definite period of time in order to visualize certain trends in growth of any type of bacteria, and the rate of its multiplication in a sample. In medical diagnosis, it is absolutely necessary to detect accurately the organisms, or bacteria, that is responsible for any illness so as to administer the right medicine and the required dosage. This means that results of culture processes obtained from patient's samples must be precise. Incubators are very useful equipment for setting and controlling of temperature for variety of purposes which includes, warming of pre-matured babies and culturing of bacteria. Mesophilic bacteria are a class of bacteria whose growth temperature range from $20^{\circ} \mathrm{C}$ to $45^{\circ} \mathrm{C}$ with optimal temperature at $37^{\circ} \mathrm{C}$ [4]. Thermophilic bacterial are those bacterial whose growth temperature range from $45^{\circ} \mathrm{C}$ to $85^{\circ} \mathrm{C}$ with optimal temperature at $55^{\circ} \mathrm{C}$ [4].

The focus of this research work is to design and Simulate Fuzzy logic temperature controller (27 ${ }^{0} \mathrm{C}$ and $55{ }^{\circ} \mathrm{C}$ ) for culturing Mesophilic and moderate thermophilic bacteria in a choice incubator by using firing angle technique.

\section{SYSTEM DESCRIPTION}

The system comprises of keypad, a controller, heating element, sensor, display, and incubator. Figure 1.1 present a simple block diagram of a temperature control system using fuzzy logic controller. The candidate controller was designed in MATLAB Simulink environment. Desired temperature (Td) is inputted through the keypad, and the display show both the desired (Td) and the Actual temperature (Ta). The fuzzy logic controller simply takes in error (e) and change in error (ce) as an input variable and then make use of the fuzzy set to modify the temperature. If the actual temperature is less than the desired temperature, the controller computealpha which is the control signal, so as to increase or reduce the temperature to the required setpoint. 


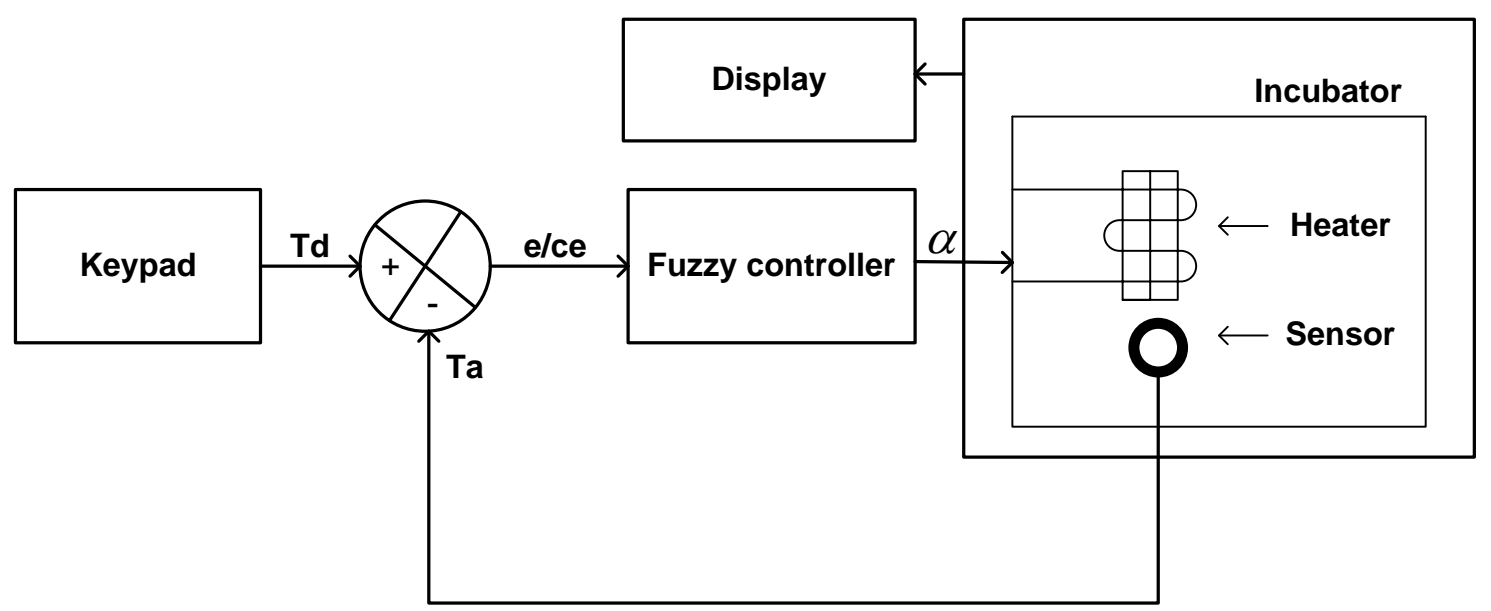

Figure 1. Simplified block diagram of a fuzzy Temperature control system

\section{SySTEM Model EquATION}

The incubator system is expected to draw power from an Alternating Current (AC) source with $240 \mathrm{~V}$ and $50 \mathrm{~Hz}$ peak voltage and frequency respectively. By Newton's law of cooling-

$\mathrm{Q}=\mathrm{hA}\left(\mathrm{T}_{\mathrm{p}}-\mathrm{T}_{\mathrm{a}}\right)$

Where $\mathrm{Q}=$ Convective heat transfer rate or local heat flux density (W)

$\mathrm{h}=$ Convection heat transfer coefficient $\left(\mathrm{W} / \mathrm{M}^{2} \mathrm{~K}\right)$

$\mathrm{A}=$ Surface area of object being heated or cooled $\left(\mathrm{M}^{2}\right)$

$\mathrm{T}_{\mathrm{p}}=$ Surface Temperature of the object $(\mathrm{K})$

$\mathrm{T}_{\mathrm{a}}=$ Bulk Temperature of surrounding fluid $(\mathrm{K})$

Assuming there is negligible heat loss to the external environment;

$\mathrm{P}=\mathrm{I}^{2} \mathrm{R}=\mathrm{IV}=\mathrm{V}^{2} / \mathrm{R}$

Where $\mathrm{P}=$ Electrical power $(\mathrm{W})$

$\mathrm{R}=$ Heater resistance $(\mathrm{Ohms})$

$\mathrm{I}=$ Current $(\mathrm{A})$

$\mathrm{V}=$ rms Voltage $(\mathrm{V})$

From (2) The Heat energy produced $\mathrm{H}$ can be represented as

$\mathrm{H}=\mathrm{I}^{2} \mathrm{Rt}$

$\frac{d}{d t} H=\mathrm{I}^{2} \mathrm{R}=\frac{V^{2}}{R}$

Equating the two rates in (1) and (4)

$\frac{V^{2}}{R}=$ h. A. $\Delta T$

$\Delta T=\frac{V^{2}}{h A R}(\mathrm{~K})$ 
Where $\Delta T$ is $\mathrm{T}_{\mathrm{p}}-\mathrm{T}_{\mathrm{a}}$

Equation (6) represents the Temperature difference or change in Temperature at any time.

Using a Triac as an actuator, the load Voltage across the heater is given by;

$$
\begin{aligned}
& V_{r m s}=\sqrt{\frac{1}{2 \pi}\left(\int_{\alpha}^{\pi} V_{M}^{2} \sin ^{2} \theta+\int_{\pi+\alpha}^{2 \pi} V_{M}^{2} \sin ^{2} \theta\right)} d \theta \\
& V_{r m s}^{2}=\frac{V_{M}^{2}}{2 \pi}((\pi-\alpha)+0.5 \sin 2 \alpha) \\
& P=\frac{V_{M}^{2}}{2 \pi R_{L}}((\pi-\alpha)+0.5 \sin 2 \alpha) \\
& \Delta T=\frac{V_{M}^{2}}{2 \pi R_{L} h A}((\pi-\alpha)+0.5 \sin 2 \alpha)
\end{aligned}
$$

The actual Temperature (Ta) is therefore the summation of the change in Temperature and the ambient Temperature (initial temperature) in the incubator; taken as $27^{\circ} \mathrm{C}$ or $300 \mathrm{~K}$.

$T a=(\Delta T+300) K$

Substituting the following values into equation (7)

$\mathrm{Vrms}=240 \mathrm{~V}$

$\mathrm{R}=2 \mathrm{~K} \Omega$

$\mathrm{A}=0.01 \mathrm{M}^{2}$

$\mathrm{h}=14.4 \mathrm{~W} / \mathrm{M}^{2} \mathrm{~K}$

Where $\mathrm{A}$ is the surface area of the heating element, and $\mathrm{h}$ is the coefficient of convective heat transfer.

Therefore,

$T a=100-0.556 \alpha+0.278 \sin 2 \alpha+300$

\section{Controller Design}

\subsection{Design of Fuzzy Logic Controller}

In the design of a fuzzy controller, the items required are: the input to the controller, Fuzzification process, the knowledge base- which is the combination of the data base and the rule base, and Defuzzification of the output of the controller. The fuzzy controller shown in figure 1.2 accepts error $\mathrm{E}$ and rate of change in error $\mathrm{CE}$ as the input variables. These inputs are fuzzified in accordance with the membership function that is provided in the data base. The controller then applies the rules in the data base; and selects the ones that are applicable as a consequent to the antecedent under consideration at a time. The result, which is the consequent of the rules so fired, is reshaped by the application of appropriate implication method. The result of the implication 
process is then aggregated and fuzzified into a single crisp value corresponding to the control action acting on the gain of the heater to either reduce or increase the temperature of the incubator.

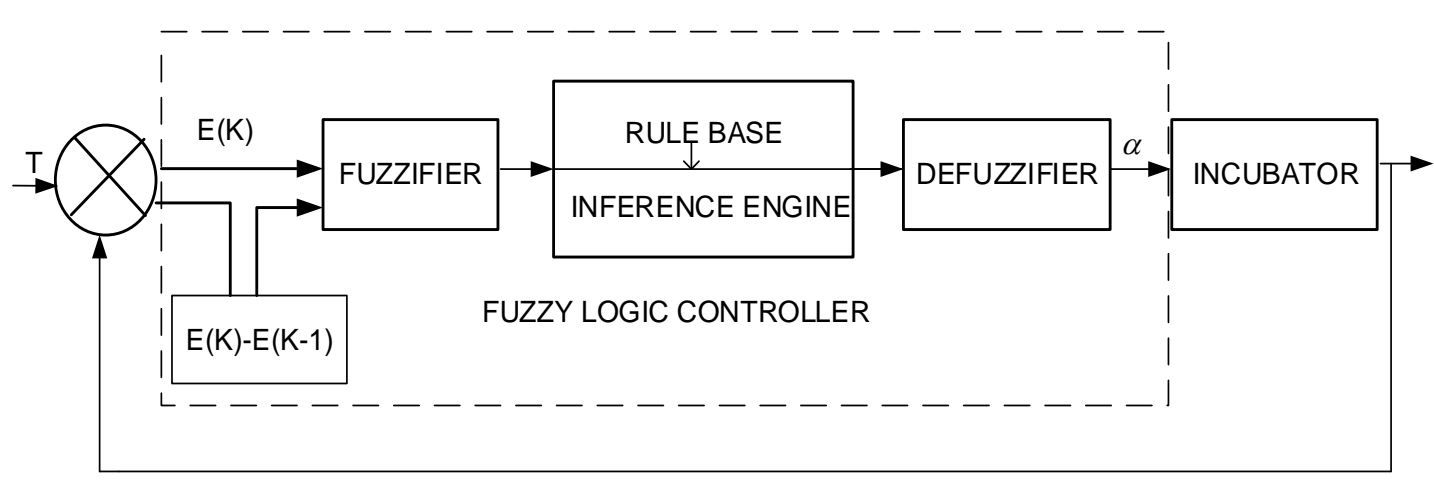

Figure 2. Fuzzy logic Controller in a closed loop system.

\subsubsection{Fuzzification}

Fuzzification is the process of converting crisp values of process variables into fuzzy sets. In this process, the universe of discourse is assigned boundaries (membership functions) in a manner similar to a universal set containing subsets of elements of the universal set [5]. The membership functions could overlap each other to a certain degree depending on the performance expectation of the controller designer. Figure 1.3 and Figure 1.4 show the membership function for the Fuzzification of input variables to the fuzzy controller, which are Error and change in error (CE) respectively.

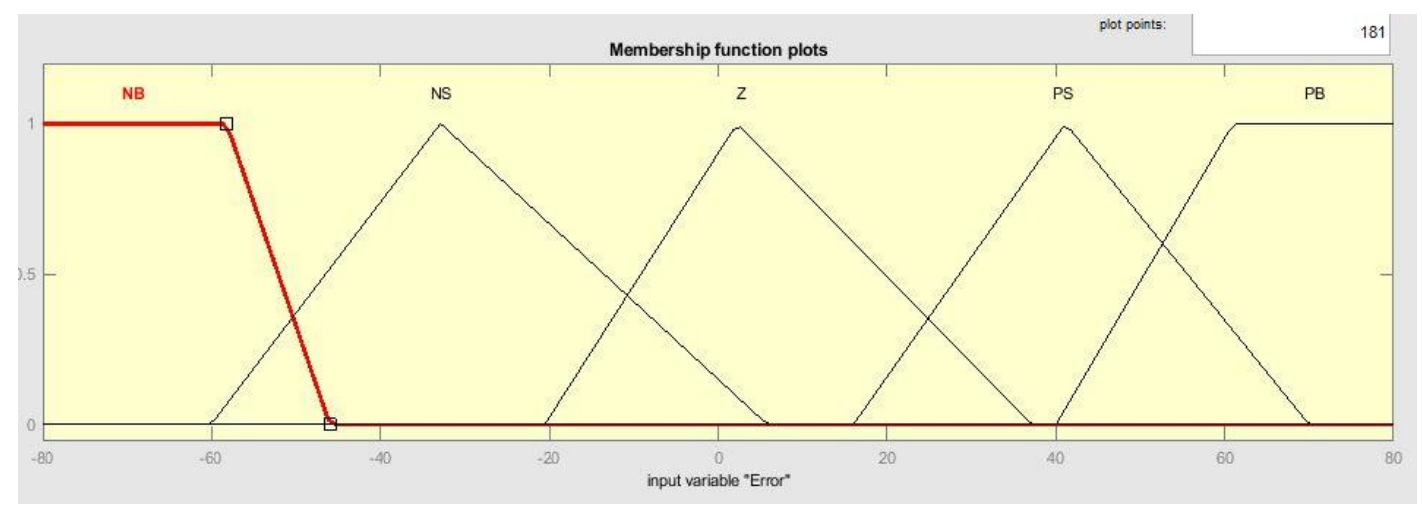

Figure 3. Input membership function error (E) 


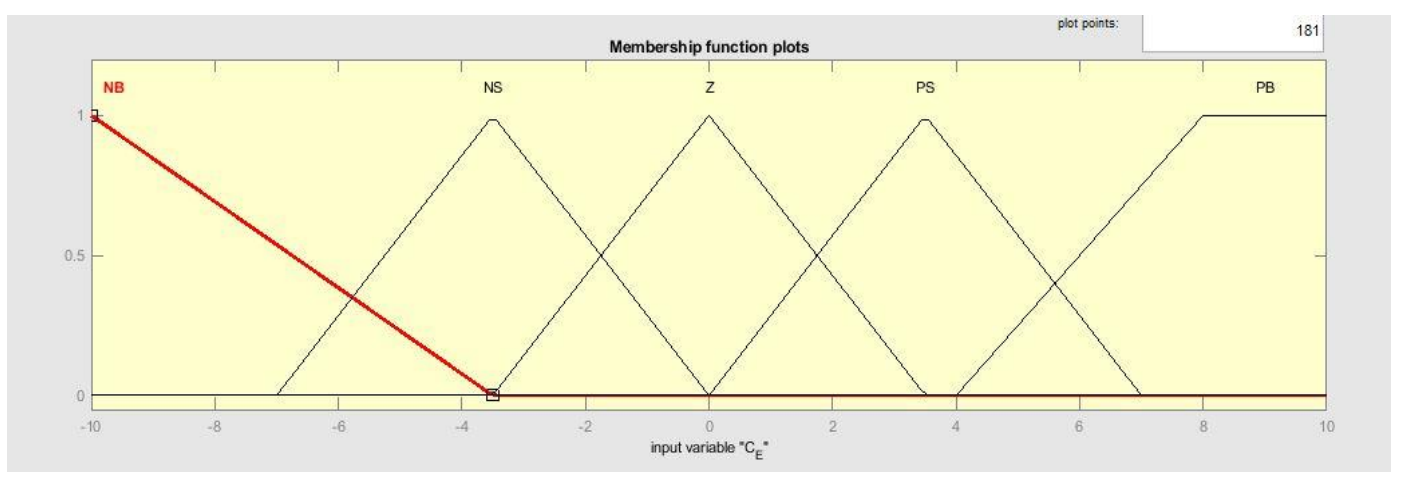

Figure 4. Input membership function of change in error (CE)

\subsubsection{Data Base}

The data base is a store which provides relevant information that enables the controller to perform an operation. The information stored in the data base is: input variables, output variables, the universe of discourse for each variable, the demarcation of the universe of discourse into sub sets or fuzzy sets with or without overlap and the membership function assigned to each fuzzy set.

Considering the task of the Laboratory incubator whose range of temperature control is typically between the room temperature 30 degree Celsius and 60 degree Celsius, the universe of discourse for output variable is chosen to be between zero and 180 degrees. In addition, the output variable is assigned four (4) linguistic terms each representing a membership function as follows: very small (VS), Medium (MED), Small (S), Big (BIG), within domains [-59.59 57.3], [57.3 157.1], [14.3 120.3] and [120.3 234] respectively.

The universe of discourse for error is between [-80 80]; it has five (5) membership functions in domains represented as [-116 -46], [-60 5.83], [-20.56 14], [16 70] and [40 116]; carrying linguistic variables as: Negative Big (NB), Negative Small (NS), Zero (Z), Positive Small (PS), and Positive Big (PB) respectively. For the change in error, the universe of discourse lies between [-10 10], having five (5) membership function namely: Negative Big (NB), Negative Small (NS), Zero (Z), Positive Small (PS), and Positive Big (PB) in the domains [-15 -3.5], [-7 0], [-3.5 3.5], $\left[\begin{array}{ll}0 & 7]\end{array}\right.$ and [4 14] respectively. Figure 1.5 show the output membership function with the linguistic variables.

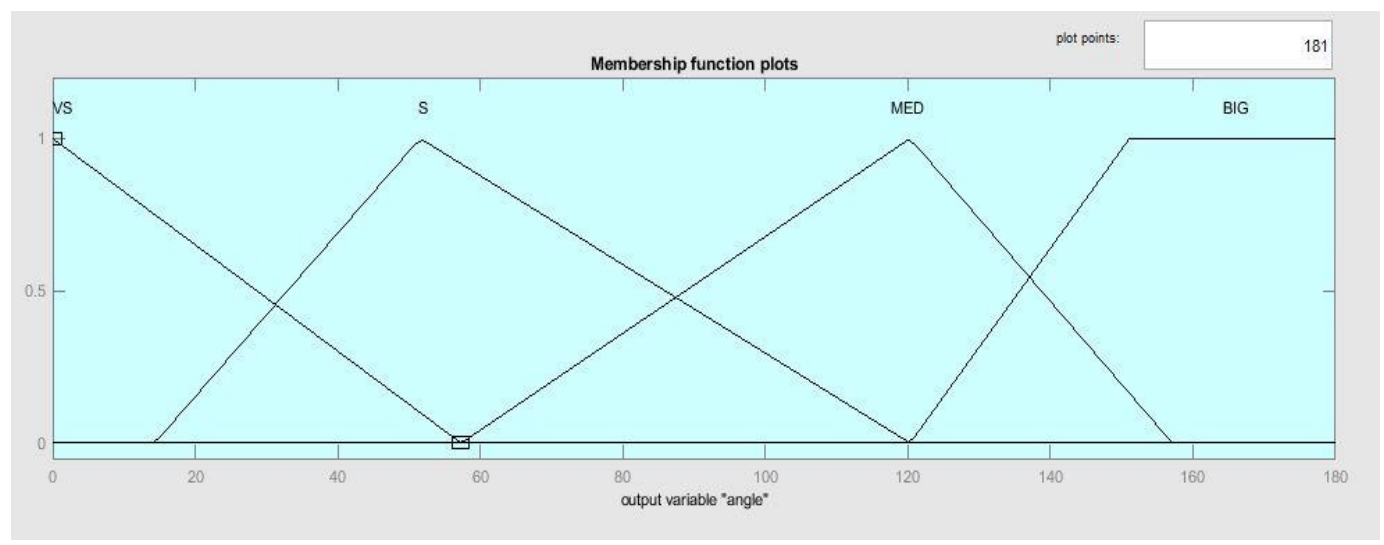

Figure 5. output membership function 


\subsubsection{Rule Base}

In the operation of the fuzzy controller, the IF THEN rules are used to represent the antecedent and the consequent part respectively. The rules that govern the action of the fuzzy controller are summarized in Table 1.1

Table 1.1 The rule base for Input and Output variables of the controller

\begin{tabular}{|l|l|l|l|l|l|}
\hline E/CE & NB & NS & $\mathbf{Z}$ & PS & PB \\
\hline NB & VS & VS & MED & MED & BIG \\
\hline NS & VS & VS & MED & S & BIG \\
\hline $\mathbf{Z}$ & VS & S & S & BIG & BIG \\
\hline PS & VS & MED & MED & MED & BIG \\
\hline PB & VS & VS & VS & MED & BIG \\
\hline
\end{tabular}

\subsubsection{Fuzzy Inference Engine}

Instead of using mathematical formula, FLC uses fuzzy rules to make a decision and generate the control action. The rules are in the form of IF-THEN statements. Inference is used to compute the rules generated from the rule base[6]. Fuzzy Logic control (FLC) has proven effective for complex, non-linear and imprecisely defined processes for which standard model-based control techniques are impractical or impossible [7]. Fuzzy Logic deals with problems that have vagueness, uncertainty and uses membership functions with values varying between 0 and 1 [8],[9]. The inference engine instructs the controller on what action to take.

\subsubsection{Defuzzification Method}

This is a process by which all the aggregated fuzzy sets are transferred into a single crisp value necessary for the control action to take place [10]. There are various Defuzzification techniques but the centroid of area method (centre of Gravity) is used for this research work. Equation 10 describes the method of Defuzzification used.

$\mathrm{Dfz}_{-} \alpha=\frac{\sum_{i=1}^{k} A i \times x i}{\sum_{i=1}^{k} A i}$

Where $x \mathrm{i}$ is a running point in a discrete universe of discourse and $A \mathrm{i}$ is its membership value in the membership function. 


\subsubsection{Simulink Model of Fuzzy Logic and the Incubator System}

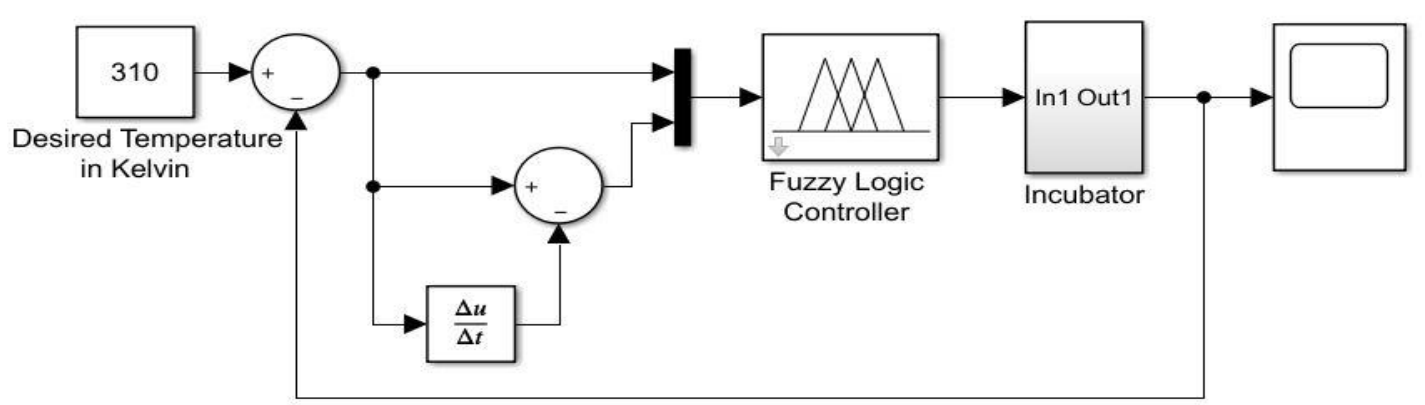

Figure 6. Simulink model of the Fuzzy controller and a Laboratory Incubator.

\subsection{7. fuzzy logic controller Flow Chart}

The Algorithm for the temperature control for the laboratory incubator was design to follow the flow chart in figure 1.7. The system compares the desired temperature with the actual temperature of the incubator. Fuzzy logic controller then computes the error, change in error and finally the firing angle alpha that will drive the incubator temperature to the desired set point.

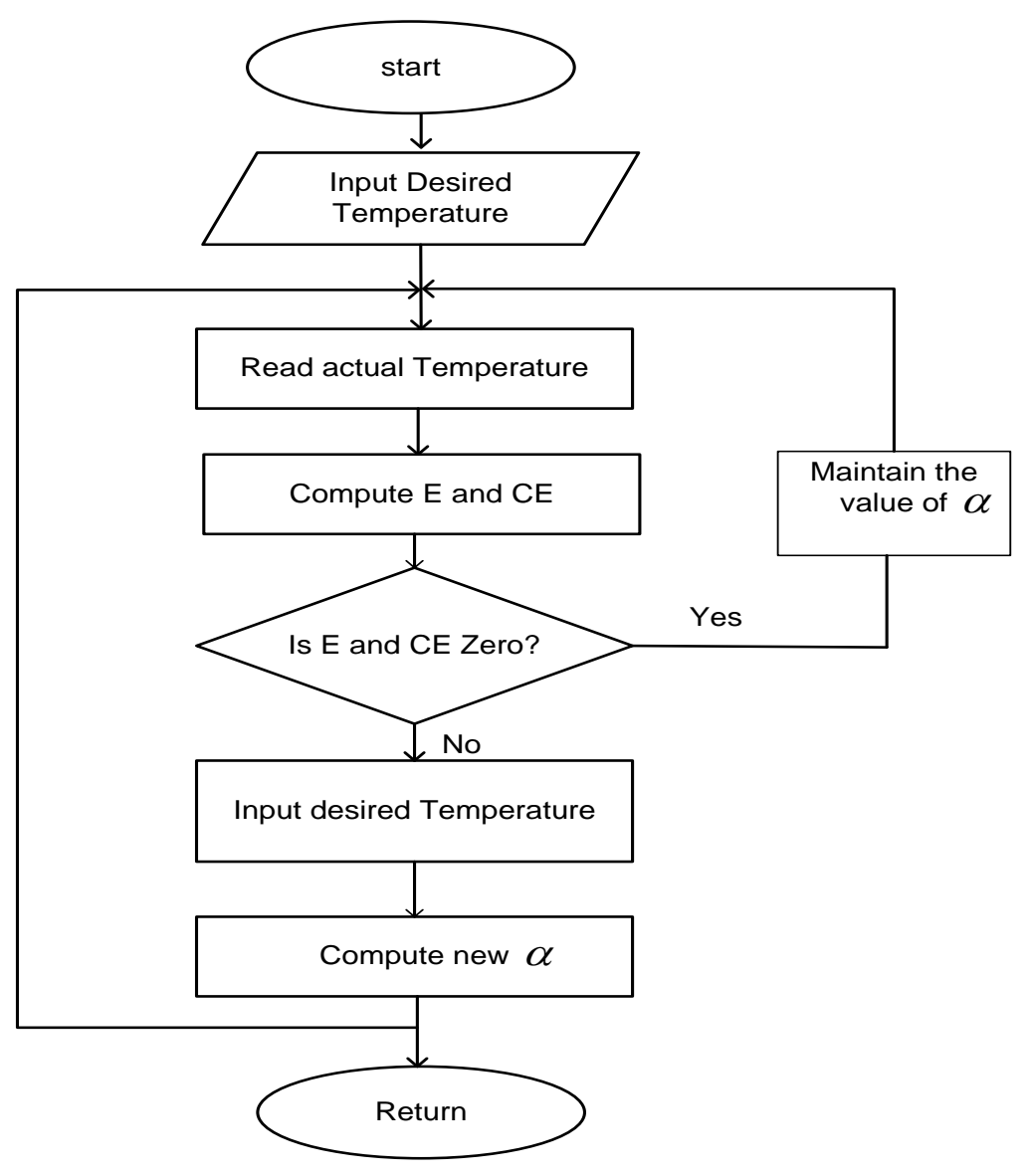

Figure 7. A flow chart for a fuzzy logic controller 


\section{RESULTS AND DISCUSSION}

The simulation result obtained in MATLAB Simulink for the optimum growth temperature for culturing Mesophilic and moderate Thermophilic bacteria is presented in figure 1.8 and figure 1.9 respectively. From the simulation result, figure 1.8 represents the fuzzy logic controller response at 310 Kelvin $\left(37^{\circ} \mathrm{C}\right)$ set point; being the optimum growth temperature for culturing Mesophilic bacteria. Similarly, figure 1.9 gives the fuzzy logic controller response at 328 Kelvin $\left(55^{\circ} \mathrm{C}\right)$ set point, which is the optimum growth temperature for moderate Thermophilic bacteria. The response show that the controller tracks at 310.5 Kelvin and 328.2 Kelvin for the two set points. The controller was able to track the temperature at the desired range smoothly with minimal overshot $(0.5 \%)$ for the two responses. The rise time were $787 \mathrm{~ms}$ and $792 \mathrm{~ms}$ for 310.5 Kelvin and 328.2 Kelvin respectively. The settling time for the 310.5 Kelvin response was $1 \mathrm{~s}$; whereas it took $2 \mathrm{~s}$ for the 328.2 Kelvin response to attain steady state.

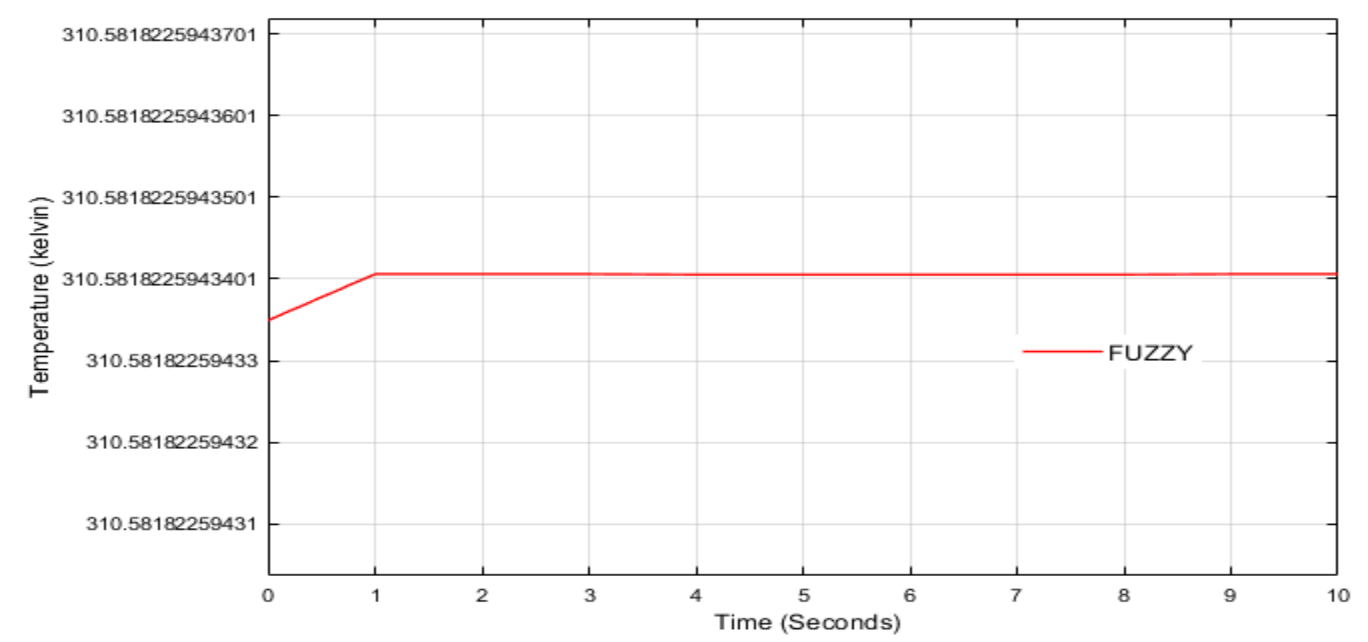

Figure 8. A Response of Fuzzy controller at a Temperature of 310K

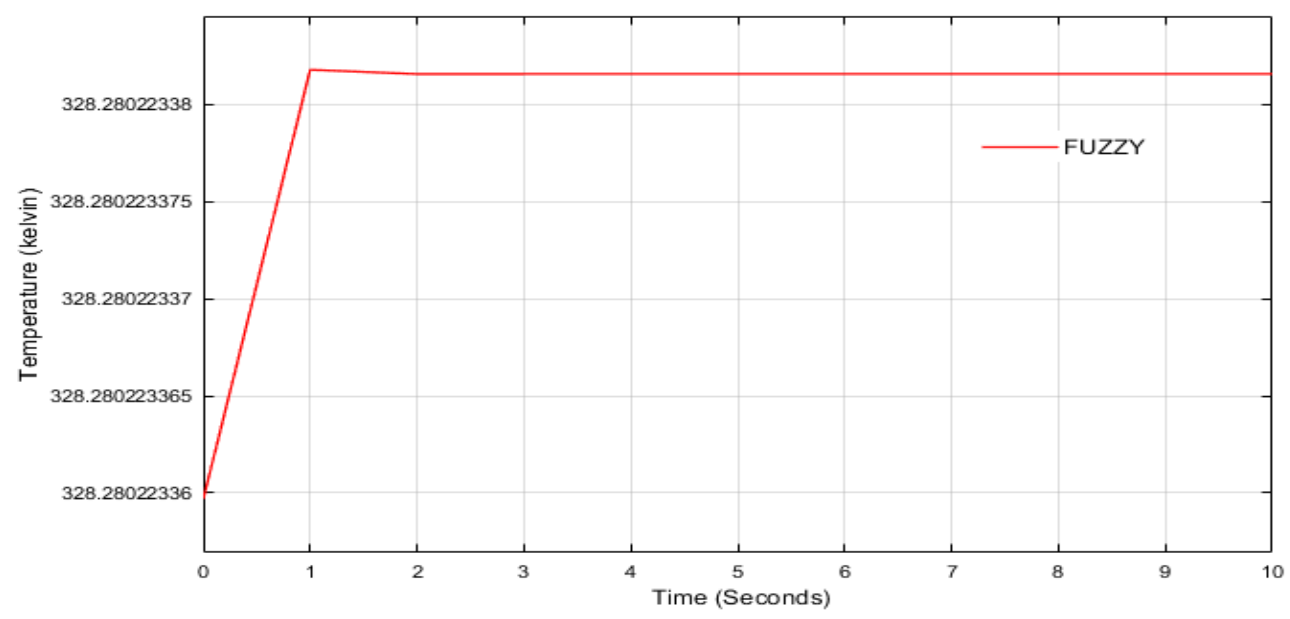

Figure 9. A response of Fuzzy controller at a temperature of $328 \mathrm{~K}$ 


\section{Conclusion}

A design of fuzzy-based temperature controller has been presented. The desired Temperatures required for optimum performance in the process of bacteria culturing with respect to Mesophilic and thermophilic bacteria were achieved with minimal offsets. The designed fuzzy-based temperature controller tracks the optimum temperature for culturing Mesophilic bacteria at $37.5^{\circ} \mathrm{C}$; and for the moderate Thermophilic bacteria at $55.2^{\circ} \mathrm{C}$ respectively. The rise time were $787 \mathrm{~ms}$ and $792 \mathrm{~ms}$ for 310.5 Kelvin and 328.2 Kelvin respectively. The settling time for the 310.5 Kelvin response was $1 \mathrm{~s}$; whereas it took $2 \mathrm{~s}$ for the 328.2 Kelvin response to attain steady state.

\section{ACKNOWLEDGEMENTS}

We are glad to express our gratitude to the Department of Electrical and Electronic Engineering, Modibbo Adama University Yola, for the support during this research work. we also want to thank our friend Engr. Jival Angeti for his support towards this research work.

\section{REFERENCES}

[1] V. Rajeev Kumar, Sunil K. Singla, "A Comparative Analysis of different Methods for the tuning of PID Controller," Internatuonal J. Electron. Commun. Electr. Eng., vol. 3, no. 2, pp. 1-17, 2013.

[2] H. Eddleman, "Optimum Temperature for Growth of Bacteria," 2013. .

[3] P. Karunakaran, "Effect of Temperature and Humidity on Bacterial Growth and Infection of Eggs," 2017.

[4] M. Furlong, "Temperature Effects on Growth Lab," 2019.

[5] A. K. Mandal, Introduction to Control Engineering Modeling, Analysis and Design, 2nd editio. New Delhi: New age International Publishers, 2012.

[6] A. A. Zanjade and J. W. Bakal, "Haedware Iplementation of Fuzzy Logic Controller for Sensorless Permanent BLDC Motor Drives," Int. J. Eng. Res. Technol., vol. 2, no. 4, pp. 717-722, 2013.

[7] C. C. Lee, "Fuzzy Logic in Control Systems:Fuzzy Logic controller," IEEE Conf. Ind. Electron. Appl., 2012.

[8] Z. K. and S. Bogdan, "Fuzzy Controller design Theory and Applications," 2012 7th IEEE Conf. Ind. Electron. Appl., 2012.

[9] S. M. un N. J. Uzair Ansari, Saqib Alam, "Jafri,"Modeling and Control of Three Phase BLDC Motor using PID with Genetic Algorithm," nternational Conf. Model. Simulation,pp.189-194., 2011.

[10] P. Singhala, D. N. Shah, and B. Patel, "Temperature Control using Fuzzy Logic," I ternational J. Instrum. Control Syst., vol. 4, no. 1, pp. 1-10, 2014. 


\section{AUTHORS}

Engr. Dr. Iliya Tizhe Thuku (Associate Professor of Instrumentation and Telecommunication Engineering) Department of Electrical and Electronic Engineering Modibbo Adama University, Yola Nigeria. He is presently a Deputy Dean Faculty of Engineering Modibbo Adama University, Yola. His area of Interest covers Instrumentation and Telecommunication.

Engr. Allo Iliya Alhassan is a Masters Student in the Department of Electrical and Electronic Engineering, Modibbo Adama University, Yola Nigeria. His area of Interest is Instrumentation and Control Engineering.
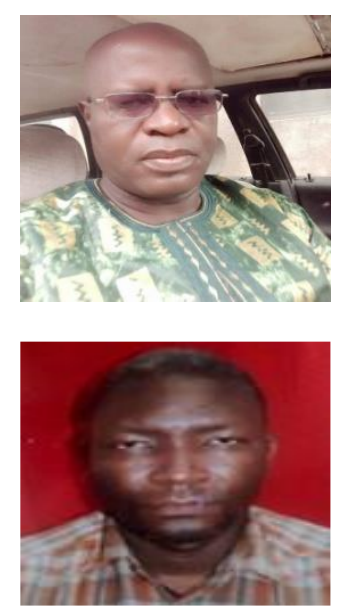

Engr. Adamu Shuaibu Kadalla is a Lecture in the Department of Electrical and Electronic Engineering, Modibbo Adama University Yola, Nigeria. He is presently a Director ICT Modibbo Adama University, Yola. His area of Interest covers Electronic and Control system.

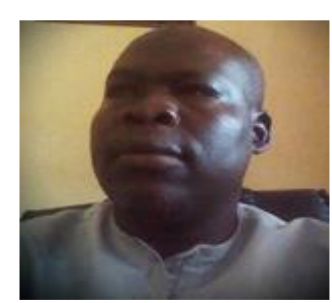

